\title{
GAYA HIDUP WANITA TINJAUAN DARI STATUS GIZI DAN PEKERJAAN
}

\author{
Oleh: \\ Endang Mulyatiningsih
}

\begin{abstract}
Abstrak
Penelitian ini bertujuan menemukan gambaran umum gaya hidup wanita terutama yang diperiukan untuk mencegah penyakit jantung. Gaya hidup tersebut meliputi perilaku pengendalian stres, aktivitas fisik, dan pengaturan makan. Lebih lanjut penelitian ini bermaksud ingin mengetahui perbedaan gaya hidup antara: 1) wanita yang memiliki status gizi kurus sehat, ideal, dan gemuk sehat, 2) wanita yang bekerja sebagai PNS, swasta, dan IRT, dan 3) wanita yang memiliki status ekonomi sedang dan tinggi. Populasi penelitian ini adalah wanita usia 30 th. -50 th. yang berdomisili di kabupaten Sleman. Sampel diambil secara bertahap menggunakan teknik multiple stage area, stratified, dan purposive sampling. Data dikumpulkan menggunakan angket dengan kuota 270 responden. Selanjutnya data dianalisis menggunakan anava satu jalur dan post hoc anova menggunakan prosechur Duncan's Multiple Range Test. Hasil penelitian menunjukkan gambaran umum gaya hidup wanita cukup baik dengan persentase skor terbesar $(59,3 \%)$ pada kategori berpeluang kecil mendapat penyakit jantung. Analisis varians menemukan ada perbedaan gaya hidup antara wanita yang memiliki status gizi kunus sehat, ideal, dan gemuk sehat dengan $F$ ratio 16,47 . Tidak ada perbedaan gaya hidup antara wanita yang bekerja sebagai PNS, swasta, dan IRT dengan F ratio 2,70. Ada perbedaan gaya hidup antara wanita yang memiliki status ekonomi sedang dan tinggi dengan $F$ ratio 4,06 .
\end{abstract}

\section{Pendahuluan}

Di negara maju, penyebab kematian dewasa ini didominasi oleh penyakit sistim sirkulasi, sistim pencernaan, neoplasma, dan metabolisme. Penyebab timbulnya penyakit ini diduga karena adanya perubahan gaya hidup. Gejala umum perubahan gaya hidup yang mengarah pada gaya hidup kurang sehat antara lain adalah: 1). Aktivitas fisik menurun sebagai akibat kemajuan teknologi. 2). Beban psikis semakin berat karena kesibukan, tantangan kerja, dan persaingan yang semakin hebat. 3). Peningkatan status ekonomi yang disertai oleh 
ketersediaan pangan semakin melimpah. Apabila kondisi ini didukung oleh selera makan yang berlebihan maka akan berakibat tubuh menjadi lebih mudah kegemukan dengan segala konsekuensinya.

Kesehatan merupakan kondisi yang tidak ternilai harganya, karena dengan badan yang sehat kita dapat bekerja dan menikmati hidup dengan lebih bermakna. Gaya hidup memberi sumbangan besar dalam status kesehatan seseorang. Menurut pendapat Ornish, D. dalam Siauw S.I. (1994) dinyatakan bahwa sebenarnya tubuh dan pikiran manusia sanggup dan mampu menyembuhkan penyakit yang diderita apabila diberi kesempatan mengubah gaya hidup yaitu dengan mengatur makannya, latihan olah raga, dan mengurangi tekanan batin serta pikiran dengan meditasi.

Permasalahan yang timbul dari penelitian ini adalah: 1). Bagaimanakah gambaran umum gaya hidup wanita di kabupaten Sleman? 2). Apakah ada perbedaan gaya hidup wanita antara yang memiliki status gizi kunus sehat, ideal, dan gemuk sehat? 3). Apakah ada perbedaan gaya hidup antara wanita yang bekerja sebagai PNS, swasta, dan IRT? 4). Apakah ada perbedaan gaya hidup antara kelompok wanita yang memiliki status ekonomi sedang dan tinggi?

Gaya hidup dalam pengertian umum dapat didefinisikan sebagai pola perilaku sehari-hari segolongan manusia di masyarakat (Pusat Pembinaan dan Pengembangan Bahasa, 1989). Konsep gaya hidup sering digunakan untuk menggambarkan kebiasaan hidup yang melekat dalam diri seseorang baik psikis, fisik, maupun sosialnya. Gaya hidup akan muncul dalam bentuk cara-cara berfikir, mengatasi masalah, mendapatkan sesuatu, bekerja, makan, penggunaan waktu, dan sebagainya.

Ada empat faktor yang menentukan status kesehatan seseorang. Menurut pusat pengontrolan penyakit di Amerika Serikat yang dikutip oleh Hutapea A. (1994), faktor-faktor tersebut meliputi perilaku kesehatan/gaya hidup, hereditas, keadaan lingkungan, dan mutu pelayanan kesehatan. Gaya hidup menempati bagian terbesar (51\%) yang dapat menentukan status kesehatan seseorang. Faktor keturunan dan mutu pelayanan kesehatan hanya berpeluang sebesar $29 \%$ saja.

Gaya hidup sehat selain untuk mencegah timbulnya penyakit dapat pula digunakan untuk menyembuhkan penyakit tanpa obat. Menunut Siauw S.I.(1994) pengubahan gaya hidup tidak saja dapat menyembuhkan penyakit jantung, tetapi juga diakui oleh hampir semua dokter ahli hipertensi sebagai suatu pengobatan 
alternatif untuk menurunkan kolesterol dan tekanan darah. Selanjutnya diterangkan pula pengubahan gaya hidup itu meliputi tiga hal vaitu: pengendalian stres, pengaturan makan, dan aktivitas fisik dengan berolahraga.

Manusia hidup selalu dihadapkan pada berbagai macam tantangan dan permasalahan yang dapat menimbulkan stres. Penyebab stres (stressor) bisa datang dari luar (eksternal) yang secara pribadi manusia tidak dapat mengendalikannya. Kuat dan lemahnya stressor akan menimbulkan reaksi berbeda tergantung pada faktor internal berupa karakteristik kepribadian manusia itu sendiri dalam menghadapi berbagai masalah. Semakin sering manusia mengahadapi masalah dan dapat mengatasinya dengan baik, maka semakin kuat dan lentur pribadi manusia tersebut untuk menghadapi masalah-masalah berikutnya yang lebih berat. Stres yang tidak ditanggulangi dan dibiarkan berlarut-lanut dapat menyebabkan penyakit psikosomatis. Menurut pendapat Cox yang dikutip oleh Aliyah A.(1992) dikemukakan jenis-jenis konsekuensi sebagai akibat dari adanya stres antara lain seperti kadar gula darah naik, denyut madi dan tekanan darah meningkat, mulut kering, banyak berkeringat, dan panas-dingin.

Pengaturan makan yang baik turut berperan dalam mempertahankan kesehatan, mencegah sakit, dan bahkan dapat digunakan untuk menyembuhkan penyakit. Petunjuk diet di U.S.A. yang ditulis oleh Robinson C.H., dan Lawler, M.R. (1992) dapat dijadikan acuan untuk membentuk pola makan yang sehat di Indonesia. Petunjuk tersebut meliputi: 1) makan cukup bervariasi; 2) memelihara berat badan ideal dengan mengkonsumsi makanan sesuai angka kebutuhan energi masing-masing; 3) menghindari makanan yang banyak mengandung lemak, asam lemak jenuh, dan kolesterol; 4) makan makanan yang banyak mengandung pati dan serat yang berimbang; 5) menghidari konsumsi gula terlalu banyak; 6) menghindari konsumsi sodium (Na) terlalu banyak: 7) menghindari minum alkohol yang berlebihan.

Olah raga yang dilakukan secara teratur sangat baik untuk memelihara kesehatan dan kebugaran tubuh. Dishman, R.G. (1990) mengemukakan manfaat olah raga senam aerobik dapat menanggulangi bermacam-macam penyakit yang sering terdapat pada umur tua antara lain: 1) menurunkan resiko kematian muda oleh penyakit kardiovaskuler, 2) memperbaiki postur tubuh yang kurang baik; 3) menghilangkan gejala general anxiety akibat stres; 4) menghilangkan gejala symptom-symptom akibat depresi: dan 5) meningkatkan kesegaran tubuh karena aliran peredaran darah lebih lancar. 
Gaya Hidup Wanita. Tinjauan dari Status Gizi dan Pekerjaan

\section{Cara penelitian}

Penelitian ini dilaksanakan pada bulan Agustus sampai dengan bulan Desember 1998. Populasi penelitian ini adalah wanita usia 30 th. -5 th. dan berdomisili di kabupaten Sleman, Daerah Istimewa Yogyakarta. Pengambilan sampel dilakukan secara bertahap melalui teknik: 1) multistage sampling untuk menentukan wilayah penelitian, 2) stratified sampling diterapkan untuk memperoleh sampel berdasarkan strata status gizi dan pekerjaan.

Karena quota sampling tidak bisa terpenuhi melalui pengambilan sampel secara acak berdasarkan strata status gizi dan pekerjaan, maka pengambilan sampel tahap berikutnya dilakukan menggunakan teknik purposive sampling. Kelompok wanita yang dikenai sampling secara purposive adalah pada wanita yang memiliki status gizi kurus sehat dan pekerjaan swasta, karena kelompok ini jumlah populasinya relatif kecil dibanding kelompok lain. Homogenitas sampel dipertimbangkan dengan mengambil lokasi penelitian pada daerah yang memiliki tingkat ekonomi hampir setara yaitu pada lingkungan perumahan dan perkantoran.

Instrumen yang digunakan untuk mengumpulkan data berupa angket. Garis besar isi angket meliputi: data pribadi yang memuat status gizi dan pekerjaan, tahapan keluarga sejahtera untuk mengungkap status ekonomi, dan daftar pernyataan tentang gaya hidup. Bentuk pernyataan yang mengungkap gaya hidup berupa pernyataan perbedaan semantik dan pernyataan yang memerlukan jawaban berskala likert. Daftar pernyataan tentang gaya hidup berisi aspek pengendalian stres, pengaturan makan, dan aktivitas fisik.

Status gizi diukur dengan menggunakan indeks massa tubuh (IMT). Cara pengukuran ini menggunakan ratio antara berat badan dan tinggi badan kuadrat dalam ukuran meter atau $\mathrm{IMT}=\frac{B B(\mathrm{~kg})}{T B(m)^{2}}$. Untuk orang dewasa pengukuran status gizi dengan cara ini sudah dianggap handal. Selanjutnya hasil pengukuran status gizi tersebut dikonsultasikan dengan ukuran baku seperti tercantum pada tabel berikut. 
Tabel 1.

Nilai Indeks Massa Tuibuh (IMT)

\begin{tabular}{|c|c|l|}
\hline Pria & Wanita & \multicolumn{1}{|c|}{ Status Gizi } \\
\hline$<18,0$ & $<17,0$ & kurus, tidak sehat \\
$18,1-20,0$ & $17,1-19,0$ & kurus sehat \\
$20,1025,0$ & $19,1-23,0$ & ideal \\
$25,1-30,0$ & $23,1-29,0$ & gemuk, sehat \\
$>30,0$ & $>29,0$ & gemuk tidak sehat \\
\hline
\end{tabular}

Sumber: Khumaidi (1993)

Mengingat mencari sampel yang memiliki berat badan ekstrim, kelebihan atau kekurangan sangat sulit, maka penelitian hanya dikenakan pada tiga kategori status gizi yang berada di tengah yaitu kategori kurus sehat, ideal. dan gemuk sehat. Ukuran ini tidak mengimplikasikan pada status kesehatan responden, tetapi hanya menggambarkan proporsi tubuh yang diukur dengan IMT tadi. Dalam hal ini bisa saja terjadi responden kategori kurus sehat tetapi memiliki keluhan satu atau dua penyakit dan sebagainya.

Gaya hidup diinterpretasikan dalam lima kategori yaitu $A_{1}, A_{2}, A B, B_{1}$, dan $B_{2}$. Kategori $A_{1}$ berarti beresiko tinggi mengidap penyakit jantung. Kategori $A_{2}$ berarti menuju arah cenderung mendapat penyakit jantung. Kategori $\mathrm{AB}$ berarti berpeluang mendapat penyakit jantung, sedangkan kategori $B_{2}$ berpeluang kecil dan $B_{1}$ tidak peka terhadap serangan jantung.

Angket diujicobakan kepada 30 responden. Validitas instrumen dipantau menggunakan analisis rasional dari teman sejawat dan komisi pembimbing. Reliabilitas instrumen diukur menggunakan tes konsistensi internal, belah dua gasal genap. Koefisien reliabilitas sebesar 0,73 sehingga angket dinyatakan dinyatakan memenuhi syarat keandalan.

Analisis data melewati tiga tahap yaitu uji persyaratan analisis, uji hipotesis, dan uji lanjut anava. Analisis varians mempersyaratkan data tersebar secara normal dan homogen. Normalitas data kemudian diuji menggunakan kemiringan kurve (skewness) dan kepuncakan kurve (kurtosis). Homogenitas varians diuji dengan Bartlett Box-F dan Cochrans' C. Setelah semua persyaratan analisis bisa terpenuhi, kemudian dilakukan pengujian hipotesis 
menggunakan analisis varians satu jalur. Uji lanjut anava dilakukan dengan menggunakan prosedur Duncan's Multiple Range Test dan prosedur Scheffe.

\section{Hasil Penelitian}

Gambaran umum gaya hidup wanita di kabupaten Sleman cukup baik, terbukti dari jumlah responden terbesar $(59,3 \%)$ berada pada kategori $\mathrm{B}_{2}$ atau berpeluang kecil mendapat penyakit jantung. Responden yang tidak peka terhadap serangan jantung atau kategori $B_{1}$ sejumlah $11,8 \%$. Gaya hidup responden yang berada pada kategori $\mathrm{AB}$ atau berpeluang mendapat penyakit jantung ada $28,6 \%$ dan sisanya sebesar $0,3 \%$ adalah responden yang menuju arah cenderung mendapat serangan jantung atau kategori $\mathrm{A}_{2}$.

Hasil pengujian hipotesis menggunakan analisis varians menemukan ada perbedaan gaya hidup antara wanita yang memiliki tubuh kurus sehat, ideal, dan gemuk sehat dengan $F$ ratio 16,47 . Uji lanjut anava menemukan suatu bukti wanita ideal memiliki gaya hidup yang lebih baik daripada wanita gemuk sehat dan kurus sehat. Wanita gemuk sehat juga memiliki gaya hidup yang lebih baik daripada wanita kurus sehat.

Responden yang memiliki tubuh ideal mencerminkan orang yang hidup terkendali. Menurut Nainggolan (1991), rahasia panjang umur adalah karena hidup terkendali setiap saat. Dari temuan penelitian ini bukan berarti setiap wanita ideal memiliki gaya hidup yang baik, karena perolehan skor terendah (145) dan skor tertinggi (204) ada pada kelompok ini.

Hasil pengujian hipotesis minor, komponen pengendalian stres terbukti ada perbedaan antara wanita kurus sehat, ideal, dan gemuk sehat dengan $F$ ratio 21,17 . Hasil uji lanjut menggunakan Duncan's Multiple Range Test dan Scheffe menemukan pengendalian stres antara wanita ideal dan gemuk sehat lebih baik dari wanita kurus sehat. Akan tetapi pengendalian stres antara wanita ideal tidak berbeda dengan wanita gemuk sehat.

Beberapa teori yang dapat mendukung hasil penelitian ini yaitu adanya keterkaitan antara status gizi dan penampilan seseorang. Apabila seseorang kurang gizi yang ditandai oleh indeks massa tubuh kurang dari standar ideal, maka akan menunjukkan roman wajah yang tegang, lemah, dan tidak bergairah. Hal lain yang sangat mendukung terjadinya stres pada kelompok status gizi ini adalah karena menjadi lebih mudah marah dan masa bodoh 
(Idrus, 1996). Selanjutnya dikemukakan pula bahwa apabila kebutuhan gizı terpenuhi yang ditampilkan oleh berat badan seimbang. maka akan menggambarkan penampilan sebaliknya. Mereka menampakkan ciri-ciri alr muka waspada tetapi tidak tegang, tingkah laku baik. bersemangat. lincah. tidur tenang dan nyenyak, seluruh organ berfungsi baik dan menunjukkan tanda-tanda sehat pada umumnya.

Hasil pengujian hipotesis minor komponen aktivitas fisik. membuktikan Ha didukung data dengan $F$ ratio 8.31. Hal ini memberi makna ada perbedaan aktivitas fisik antara wanita kurus sehat, ideal, dan gemuk sehat. Hasil uji lanjut menggunakan Duncan's menemukan wanita gemuk sehat memiliki aktivitas yang lebih rendah daripada wanita ideal dan kurus sehat. Sedangkan antara wanita ideal dan kurus sehat terbukti tidak ada perbedaan dalam hal aktivitas fisik.

Hasil penelitian di atas didukung oleh penelitian Soeyoko dan Ircham (1991) yang mengemukakan bahwa orang yang kegemukan lebih mudah mengantuk karena di dalam tubuhnya lebih banyak tertimbun $\mathrm{CO}_{2}$. Khumaidi (1990) mengamati orientasi kegiatan dari orang yang kegemukan lebih tertuju pada kegiatan yang tidak banyak mengeluarkan tenaga seperti berjalan pelanpelan, bekerja sambil duduk, dan biasanya kurang berminat melakukan olah raga.

Hasil pengujian hipotesis minor komponen pengaturan makan. menemukan ada perbedaan pengaturan makan antara wanita yang memiliki status gizi kurus sehat, ideal, dan gemuk sehat dengan $F$ ratio 11.8. Post hoc anava dengan menggunakan prosedur Duncan's maupun Scheffe, membuktikan wanita ideal memiliki pengaturan makan lebih baik daripada wanita gemuk sehat dan kurus sehat. Dua kelompok wanita yang disebut terakhir ini tidak menunjukkan perbedaan yang nyata dalam pengaturan makan.

Hasil penelitian ini didukung oleh Boedhi. D. dkk. (1991) yang menjelaskan bahwa akibat pengaturan makan yang kurang baik akan menyebabkan dua masalah yaitu kegemukan dan kekurusan. Kegemukan dapat terjadi karena asupan energi yang berlebihan dan mobilitas menurun. Kekurusan dapat terjadi karena asupan energi vang kurang seımbang dengan aktivitas fisik. Meskipun banyak faktor yang dapat mempengaruhi status gizi 
seseorang, namun keseimbangan antara pemasukan energi dan pengeluarannya untuk aktivitas fisik tetap menjadi penentu utama keadaan gizi seseorang.

Manusia memiliki keseimbangan hidup, pada satu sisi mereka memiliki kekurangan tetapi di sisi lain mereka juga mempunyai kelebihan. Hal tersebut dapat terlihat dari post hoc anava, yang dilakukan dengan menggunakan prosedur Duncan's dan Scheffe. Tiap-tiap komponen gaya hidup dari kelompok status gizi yang berbeda terdapat beberapa karakteristik yang menonjol. Pada komponen pengendalian stres, terbukti kelompok wanita kurus sehat memiliki skor lebih rendah dari kelompok lain. Berbeda halnya pada komponen aktivitas fisik dimana kelompok ini memiliki skor yang lebih unggul. Namun secara umum kelompok wanita ideal memiliki kelebihan pada tiap-tiap komponen gaya hidup dibanding kelompok status gizi lain.

Pengujian hipotesis pada variabel pekerjaan, membuktikan tidak ada perbedaan gaya hidup antara wanita yang bekerja sebagai PNS, swasta, dan IRT dengan F ratio 2,70. Pada komponen pengendalian stres ternyata diperoleh F ratio 3,57 sehingga dapat dikatakan ada perbedaan pengendalian stres antara wanita yang bekerja sebagai PNS, swasta, dan IRT. Post hoc anava menggunakan prosedur Duncan's menemukan kelompok PNS memiliki tingkat pengendalian stres lebih baik daripada kelompok swasta, tetapi tidak berbeda nyata dengan kelompok IRT, dan kelompok IRT juga tidak berbeda nyata dengan kelompok swasta.

Hasil penelitian ini didukung oleh penelitian Tika S. (1995) yang memperoleh temuan ibu yang bekerja sebagai buruh, relatif kurang bahagia bila dibandingkan dengan ibu yang tidak bekerja. Ibu yang bekerja di bidang jasa mendapatkan resiko stres yang relatif kecil daripada ibu yang tidak bekerja.

Hasil pengujian hipotesis minor komponen pengaturan makan ditemukan tidak ada perbedaan antara kolompok PNS, swasta, dan IRT dengan harga $F$ ratio 0,06 . Tidak terdapatnya perbedaan pengaturan makan antara PNS, swasta, dan IRT dapat dijelaskan oleh variabel status ekonomi, dimana kelompok status ekonomi tinggi memiliki pengaturan makan yang lebih baik daripada kelompok status ekonomi sedang. Pekerjaan ibu bukan penentu utama status ekonomi keluarga, meskipun diaku konstribusi pekerja wanita pada pendapatan rumah tangga mampu memperbaiki taraf kesejahteraan keluarga. 


\section{Kesimpulan}

Berdasarkan hasil pengujian hipotesis dan pembahasan tentang gaya hidup wanita dari tinjauan status gizi dapat disimpulkan:

1) Gambaran umum gaya hidup wanita di kabupaten Sleman cukup baik. Perolehan skor terbesar ada pada kategori berpeluang kecil mendapat penyakit jantung.

2) Ada perbedaan gaya hidup antara wanita kurus sehat, ideal. dan gemuk sehat. Wanita ideal memiliki gaya hidup yang lebih baik dari dua kelompok pembandingnya.

3) Ada perbedaan pengendalian stres, aktivitas fisik, dan pengaturan makan antara kelompok wanita yang memiliki status gizi kurus sehat, ideal, dan gemuk sehat. Wanita kurus sehat memiliki pengendalian stres yang lebih lemah daripada kelompok ideal dan gemuk sehat. Wanita gemuk sehat memiliki aktivitas fisik yang lebih rendah dari wanita ideal dan kurus sehat. Antara wanita kurus sehat dan gemuk sehat keduanya memiliki pengaturan makan yang lebih rendah daripada wanita ideal.

4) Tidak terdapat perbedaan gaya hidup antara kelompok wanita yang bekerja sebagai PNS, swasta, dan IRT. Pada komponen pengendalian stres, kelompok wanita yang bekerja di sektor swasta memiliki skor yang lebih rendah daripada kelompok wanita yang bekerja sebagai PNS dan IRT.5).

5) Ada perbedaan gaya hidup antara wanita yang memiliki status ekonomi sedang dan status ekonomi tinggi. Perbedaan gaya hidup tersebut ditunjukkan oleh pengaturan makanannya, dimana kelompok wanita yang memiliki status ekonomi tinggi lebih baik daripada kelompok status ekonomi sedang.

\section{Implikasi}

Dengan temuan-temuan yang diperoleh dari penelitian ini, diharapkan dapat menjadi bahan pertimbangan khususnya bagi wanita untuk memilih model gaya hidup sehat. Menjalani hidup sesuai dengan anjuran yang ditulis pada penelitian ini diharapkan dapat mencegah datangnya sakit, mempercepat kesembuhan penyakit, dan dapat memperpanjang umur.

Berdasarkan hasil penelitian dapat diketahui bahwa status gizi ideal memiliki kecenderungan gaya hidup yang lebih baik daripada kelompok status gizi lain. Bagi dua kelompok yang berada di atas status gizi ideal maupun 
di bawahnya, dapat merujuk hasil penelitian ini agar mereka bisa menutup kekurangannya dan mempertahankan kelebihan yang sudah dimiliki. Bagi kelompok status gizi gemuk sehat, dapat menjalani hidup yang lebih sehat lagi apabila mau melakukan olah raga dan memperbaiki kembali pola makannya. Bagi kelompok status gizi kurus sehat, agar lebih memperhatikan kesehatan pribadinya, terutama pada hal-hal yang berkaitan dengan kesehatan jiwanya.

Penelitian ini menemukan stres masih menjadi masalah utama bagi wanita, khususnya wanita yang bekerja di sektor swasta. Kelenturan pribadi dalam menghadapi berbagai masalah hidup perlu ditingkatkan karena stressor akan datang kapan saja, dimana saja dan tanpa mengenal siapa. Bagi wanita yang bekerja, stres kemungkinan banyak disebabkan oleh kesibukannya. Alternafif untuk mengatasi masalah ini dapat dilakukan dengan membagi waktu sebaik-baiknya antara pekerjaan dan rumah tangga. Bagaimanapun suksesnya dalam berkarier, seorang ibu akan tetap dituntut menjadi pengayom anak-anaknya yang harus memperhatikan kelangsungan hidupnya. Seorang ibu juga harus dapat menjadi teman hidup bagi suami yang diharapkan dapat memberi kesejukan di dalam rumah tangga.

Status ekonomi keluarga dapat menjelaskan adanya perbedaan gaya hidup. Temuan ini memberi isyarat, bahwa ekonomi mutlak diperlukan untuk memilih model gaya hidup yang baik. Adanya jaminan hidup dapat memberi ketenangan dan ketenteraman jiwa. Sebagai manusia yang beriman, meningkatkan kualitas hidup boleh diupayakan asalkan dengan cara-cara yang wajar, jujur, tidak terlalu ambisius, dan mau menang sendiri. Meraih cita-cita dengan bekerja keras dan memaksakan diri, justru hanya akan menjerumuskan pada kehidupan yang lebih sulit.

\section{Daftar Pustaka}

Aliyah, A. (1992). Stres dan kerja, suatu perspektif manajerial. Cakrawala Pendidikan. No. 3, Th. XI, November 1992, Penerbit Pusat Pengabdian Pada Masyarakat, IKIP Yogyakarta. 
Jurnal Penelitian dan Evaluasi, Nomor 2, Tahun II, 2000

Boedhi, D. (1993). Epidemologi penyakit kardiovaskular dan masalah gizi pada golongan lanjut usia di Indonesia. Prosiding Widyakarya Pangan dan Gizi. Maret 1993, hlm. 96 - 115.

Dishman, R.G. (1990). Exercise adherence its impact on public health. Georgia: Georgia University Press.

Hutapea, A. (1994). Menuju gaya hidup sehat. Jakarta: PT Gramedia Pustaka Utama.

Idrus. (1996). Kiat membina tubuh modern. Solo: CV Aneka.

Khumaidi, (1990). Gizi untuk orang dewasa. Makalah dalam pelatihan singkat gizi kelompok khusus. Tanggal 1 - 28 Juli 1990.

(1993). Penyusunan kecukupan gizi berbagai kelompok fisiologis dan kegiatan fisik. Bogor: PAU - IPB.

Nainggolan (1993). Dokter alamiah. Bandung: University Offset.

Pusat Pembinaan dan Pengembangan Bahasa (1989). Kamus besar Bahasa Indonesia. Jakarta: Balai Pustaka

Robinson, C.H. and Lawler, M.R. (1982). Normal and therapeutic nutrition. New York: Mac Millan Publishing Co. Inc.

Siauw, S.I. (1994). Hipertensi. Jakarta: Dabara Publishers.

Soeyoko dan Ircham. (1991). Penyakit umum yang perlu diketahui banyak orang. Yogyakarta: Liberty Press.

Tika S. (1995). Faktor-faktor yang mempengaruhi kebahagiaan perkawinan pada ibu bekerja dan tidak bekerja Media Gizi dan Keluarga. Tahun XIX No 1, hlm. 9-17. 